DOI: $10.15193 / \mathrm{ZNTJ} / 2018 / 116 / 243$

\author{
MALGORZATA DULA, JAN MATRAS, EUGENIUSZ R. GRELA, \\ IGNACY NIEDZIÓŁKA
}

\title{
ANTIOXIDANT AND OTHER HEALTH PROMOTING PROPERTIES OF HERBS
}

\begin{abstract}
Su m m a r y
Many component contained in the plants we usually eat are characterized by antioxidant properties, for example polyphenols effectively neutralize free radicals and other reactive oxygen species. The antioxidant potential of some herbal plants is many times higher than that of fruits and vegetables and therefore there has been a growing interest in the active substances contained therein. An improper diet, such as the one rich in lipids, adversely affects the level of free radicals in the body; so it is very important to choose to eat foods with a high antioxidant potential. The oxidation reactions that occur in food products have a detrimental impact on their nutritional value and sensory properties, such as taste, smell, color and texture. Antioxidants added to food can effectively counteract those changes, therefore there are sought natural food ingredients with antioxidant properties to replace synthetic antioxidants, such as BHA, BHT, which are often used in food. Some herbal spices have an anti-inflammatory and antibacterial effect. Moreover, they can stimulate appetite, increase the secretion of digestive juices and improve the absorption of nutrients. A diet enriched with suitable herbs or preparations obtained from them, mainly owing to the antioxidants contained therein, improves the functioning of the organism and prevents the development of certain diseases, such as cancer or atherosclerosis of blood vessels.
\end{abstract}

Key words: herbs, antioxidants, properties, effects, health

\section{Introduction}

The increased consumption of foods rich in substances having antioxidant properties has a beneficial effect on the organism, as evidenced by numerous scientific reports $[30,46,24]$. Herbs play a special role in the human and animal nutrition for they contain biologically active substances, such as phenolic compounds, including phenol-

Mgr M. Dula, prof. dr hab. J. Matras, prof. dr hab. E. R. Grela, Instytut Żywienia Zwierząt i Bromatologii, Wydz. Biologii, Nauk o Zwierzętach i Biogospodarki, Uniwersytet Przyrodniczy w Lublinie, ul. Akademicka 13, 20-950 Lublin, dr hab. I. Niedziółka, prof. nadzw., Katedra Maszyn Rolniczych, Leśnych $i$ Transportowych, Wydz. Inżynierii Produkcji, Uniwersytet Przyrodniczy w Lublinie, ul. Glęboka 28, 20-612 Lublin.Kontakt: malgorzata.dula@up.lublin.pl 
ic acids, flavonoids, carotenoids and vitamin $\mathrm{C}$; owing to their properties, those substances enhance, among other things, appetite, immunity and cancer prevention [13]. Also they best interact with the circulatory and nervous systems [17], fight diabetes, cataracts, rheumatoid arthritis, Alzheimer's disease, allergy, liver and kidney diseases, and have antibacterial, antifungal, antipyretic, antispasmodic, anti-inflammatory as well as expectorant and antitussive properties [9]. Herbs, their parts (seeds, leaves, flowers, roots, rhizomes) contain active secondary metabolites that can affect the organism of people and animals [10]. Beside the classical herbs with the aforementioned properties, spice herbs are used in human and animal nutrition [25, 40]. They are dried parts of plants and include roots (e.g. ginger), bark (e.g. cinnamon), stems, leaves (e.g. savory, marjoram or tarragon), flowers or their parts (carnations, saffron), fruits (e.g. pepper, allspice) or seeds (e.g. nutmeg, mustard, cardamom). The properties of spice herbs result from the occurrence of specific, biologically active substances therein. Those compounds are responsible for the flavoring properties of spices; that is why they are used as food additives. Spices are also considered to be functional ingredients that have a beneficial effect on the human organism. There are nearly 130 species of herbal plants cultivated in Europe on an area of 70.000 hectares and the main EU producers include Germany, France and Spain. Poland belongs to the main European producers of herbs too. Most of the herbal raw materials is utilized by the pharmaceutical industry [14]. Except for the cultivated herbal plants, some herb material is derived from wild-growing plants. Among the countries that are leaders in producing herbs of natural origin are: Bulgaria, Albania and Turkey [31]. The value of the herbs and spices market in the EU has been on the rise since 2004 and the demand for herbal material has grown sharply. One of the greatest values of herbs is their therapeutic effect on the processes occurring in human body and the fact that they facilitate the absorption of nutrients [28]. The objective of the paper was to present the most current knowledge concerning, mainly the action of antioxidative substances contained in herbs and preparations thereof on the human organism.

\section{Antioxidants and their role}

Antioxidant is defined as a substance that is much less concentrated than an oxidized substrate; it significantly delays or prevents the oxidation of that substrate [12, 30]. A mixture of two or more antioxidants is sometimes more effective than the same amount of only one of them, therefore using the properly compiled herbal mixtures is much more effective than applying just a single herb [37]. The mechanism of antioxidant action consists in the fact that it interacts with primary oxidation products (mainly lipids) and forms poorly-reactive radicals and thus the formation is prevented of toxic alcohols, ketones, aldehydes, and acids. It is important to prevent the oxidation of polyunsaturated fatty acids (PUFAs), which are very vulnerable to the oxidizing effects of 
oxygen-free radicals (FR) and other reactive oxygen species (ROS). The reactive oxygen species easily react with cellular components, such as lipids, proteins or DNA and the effect of their action may be the damage of biological membrane associated with the loss of their activity and of functions or the inactivation of cellular enzymes. Also they can generate the inappropriate activity or inactivation of all the enzymes [36].

Free radicals are molecules with one or more unpaired electrons on the outer orbit. In order to join the electron, they exhibit a high chemical activity and oxidize each compound they contact. Most often, free radicals in the body attack the compounds with double bonds in the molecules, i.e. proteins, DNA, PUFAs in cell membranes and polysaccharides. The following radicals and other ROS occur in the biological systems: superoxide $\mathrm{O}_{2}^{-}$, hydroxyl $\mathrm{OH}$, perhydroxyl radical $\mathrm{HO}_{2}$, peroxide $\mathrm{ROO}$, alkoxy $\mathrm{RO}$, hydrogen peroxide $\mathrm{H}_{2} \mathrm{O}_{2}$, singlet oxygen ${ }^{1} \mathrm{O}_{2}$, hydroxyl radical $\mathrm{HO}$, nitric oxide $\mathrm{NO}$, acids: peroxonitrous $\left(\mathrm{HONO}_{3}\right)$ and hypochlorous ( $\left.\mathrm{HClO}\right)$ [7]. Free radicals are dangerous in the diseases of diabetes, atherosclerosis, polyneuropathy and cancer [35]; they also contribute to degenerative cellular changes, which, in turn, can lead to human death [8].

Free radicals are formed in the body both during the initiation of peroxidation of PUFAs in the mucous membranes and in the processes of homolytic tearing of bonds or as a result of electron transfer between the molecules of chemical compounds. Lipid peroxidation is a very undesirable phenomenon because during this process new radicals are again produced, which manifests itself in the loss of cell membrane function. Lipid peroxidation is a cause of inhibited enzyme activity in cell membranes as well as of impaired transport of protein, such as $\mathrm{Ca}^{2+}$ ATPase and $\mathrm{Mg}^{2+}$ ATPase. As a result of those undesirable processes, plasmatic and lysosomal membranes lose their natural functions. Free radicals appear owing to both the external and the internal factors. The external factors include: ionizing radiation, being in a polluted environment, intense visible and thermal radiation, prolonged sunbathing and nicotine smoke. As regards the internal factors, they include biological oxidation in the respiratory chain, autooxidation reactions, and enzymatic metabolism of arachidonic acid [2]. Oxygen is essential for life in biological oxidation processes and on the other hand its molecule takes part in the formation of free radicals. In a normally functioning organism, approx. $5 \%$ of oxygen is converted to free radicals, the number of which in the body is variable as it depends on many sources of their origin. Therefore one of the most radical-friendly elements is oxygen, wherein the free radicals are reactive oxygen species (ROS) [4].

For the proper functioning of the body, it is very important to maintain a balance between the number of free radicals in the body and antioxidant mechanisms because, as a result of an excess of free radicals and inadequate antioxidant protection, that balance could possibly be disrupted and this would cause an oxidative stress (oxygen shock), which in turn causes a damage at the cellular level and thus it contributes to the 
formation of various degenerative diseases. A consequence of oxidative stress is the lipid peroxidation, protein degradation, DNA damage, increased catabolism of adenine nucleotides, damage of mitochondria, NADH synthesis reduction, lowering the concentration of ATP in a cell, increase of cell membrane permeability and low concentrations of both the enzymatic and the non-enzymatic antioxidants [23]. The natural antioxidants contained in herbal spices help reduce oxidative stress [44].

\section{Diseases caused by the action of ROS}

Reactive oxygen species play different roles in the development of many diseases and they are also important in the aging process of cells and their apoptosis. The consequences of free radical action are the following diseases: atherosclerosis, diabetes, rheumatism, pancreatitis, cancer, myocardial infarction, stroke, neurodegenerative diseases (Alzheimer's and Parkinson's diseases) $[39,43]$ and aging. Another negative effect of free radicals is DNA damage, which leads to cancer [15].

Enzymatic and non-enzymatic cell defense mechanisms consist in maintaining proper homeostasis, i.e. the balance between the formation of reactive oxygen species and their biological deactivation (the so-called pro-oxidant-antioxidant homeostasis). They can be presented in the following order: anti-generating oxygen reduction products and singlet oxygen by removing catalysts of the reactions, which are the source of their origin, slowing down both the formation of free radicals and the reactions, which are non-radical but generate reactive oxygen species, removal of reaction products of reactive oxygen species from the cell and repair of damage generated by free radicals. Human body produces defense mechanisms that enable the proper functioning of cells in the presence of active oxygen species. The protection from harmful effects of free radicals is provided by cellular enzymes, which are part of the internal system consisting of proteins and their mineral co-enzymes as well as of enzymatic reaction products, which include: superoxide dismutase (SOD), catalase (CAT), peroxidase (GSH-Px). Another defense mechanism includes non-enzymatic antioxidants belonging to an external system composed of nutrients or obtained in the form of: supplements, vitamins, minerals and trace elements. It has been reported that some antioxidants of plant origin raise the level of endogenous antioxidants owing to the impact on the expression of genes encoding the above-mentioned enzymes. Therefore we should enrich our diet with the plant-derived antioxidants, whose main role is to support the intra-systemic antioxidant defense [23].

\section{Antioxidant and medicinal properties of herbs}

It has been reported that the extracts of herbs, for example damask rose (Rosa Damascena) oil or ginkgo biloba (Ginkgo biloba) leaves, have antioxidant properties. In his studies, Papageorgiou [33] reported that rosemary, marjoram and peppermint 
showed the highest antioxidant properties. A large number of natural compounds supplied with food have antioxidant properties, for example polyphenols (flavonoids, phenolic acids, caffeic acid) from mistletoe (Viscum album) are effective scavengers of free radicals and this means that they neutralize FR and reactive oxygen or nitrogen species. Curcumin (Curcuma longa) has strong antioxidant properties. It prevents peroxidation of membrane lipids and protects it against loss of integrity. Products of metabolism or degradation reaction of curcumin, i.e. vanillin and ferulic acid, have strong antioxidant properties, whereby it has become a potential drug for treating Alzheimer's disease by inhibiting the formation of amyloid deposits in the body [7]. Curcumin prevents venous thrombosis and protects against myocardial infarction. It shows very strong therapeutic and pharmacological properties (anti-inflammatory, antimicrobial, anticancer) [26] at diabetic complications, such as neuropathy, nephropathy, retinopathy or cardiomyopathy, which are the major causes of diseases and mortality [20].

Polyphenols, mainly flavonoids, form a very broad spectrum of antioxidants, because they mainly act as donors of electron or hydrogen, they can stabilize or relocate unpaired electrons by the conjugated double bonds, they chelate metal ions, inhibit breakdown of oxidases, they chain radical reactions and also they stabilize free radicals by their complexity or hydrogenation [42]. Epidemiological studies suggest that the consumption of flavonoids can reduce the risk of cancer, such as mouth and throat cancer, stomach, pancreas, intestines, liver, prostate, ovary, breast and lungs cancers [29].

The antioxidant properties of polyphenols depend, to a great extent, on their molecular structure and above all on the number and distribution of hydroxyl groups. Polyphenols play a very important role in protecting the skin against harmful UV rays as they act as natural filters through neutralizing, as early as on the level of initiation, free radicals that damage the epidermal lipid layer. Based on that action, the chances to reduce the risk of cancer are increased [34]. An important source of polyphenols are rosemary (Rosmarinus officinalis L.) and sage (Salvia officinalis L.) and compounds responsible for those properties are carnosol and carnosic acids, which are up to $90 \%$ responsible for the antioxidant properties of herbal preparations. They also play an important role in inhibiting lipid peroxidation. They exhibit antibacterial, antiallergic, antiviral and analgesic effects. They also reduce the risk of cancer, atherosclerosis, diabetes, which can result from the action of free radicals [46]. Polyphenols also play an important role in the removal of ROS, which are the initiators of platelet activation processes leading to thrombosis. The latter severely shortens the life expectancy. Anticoagulant properties are shown by ginkgo (Ginkgo biloba) leaves as they are rich in flavonol substances and biflavonoids [22].

Very important is the occurrence of caffeic, ferulic and p-coumaric acids in lemon balm (Melissa officinalis L.); they are compounds with strong antioxidant and anti- 
tumor activities [6]. Soodi et al. [41] have studied its effect on memory - the cholinergic properties of the extract can help improve memory. Garlic (Allium sativum) is particularly noteworthy as it has the highest ability to bind superoxide and hydroxyl radicals. High natural antioxidant properties found in garlic are ascribed to allicin and phytoncides. This herb increases the secretion of bile, digestive juices, it lowers blood pressure, antithrombotic and antiatherogenic activity and it negatively impacts on Gram-positive and Gram-negative bacteria. Also it has been reported that it helps in the eradication of Helicobacter pylori, it inhibits the development of tuberculosis bacilli and it has an anti-parasitic effect. [16].

Green tea leaves are one of the richest sources of polyphenols. Antioxidants, especially catechins in green tea (Camellia sinensis), form complexes with cholesterol and thereby they reduce its absorption from the digestive system. They demonstrate strong antioxidant properties since they prevent oxidation of low density lipoprotein cholesterol (LDL), a source of free radicals, and thus they protect against oxidation of the high density lipoprotein (HDL), which prevents atherosclerosis [3, 32]. Of all the tested teas, the green, white and black teas had the highest antioxidant activity compared to chamomile herbal teas, peppermint and Pu-erh tea, which exhibited lower antioxidant activity [38].

According to Ahmad [1] and Kumar \& Pandey [21], flavonoids (quercetin, naringenin) are a very important group of polyphenolic antioxidants contained in plants; they possess anti-inflammatory, anti-atherogenic, antidiabetic, antiemetic, spasmolytic, and diuretic properties. They are characterized by a very high antioxidant action manifested in the extinguishing of free oxygen radicals and their reactive forms. They also stimulate the absorption of vitamin $\mathrm{C}$ from the gastrointestinal tract and also favorably impact human metabolism. They exhibit antimicrobial properties against a wide range of microorganisms, including Enterobacter spp., Helicobacter pylori, Klebsiella pneumoniae, Pseudomonas aeruginosa, Salmonella typhimurium, Vibrio cholerae. Flavonoids are capable of neutralizing certain endotoxins and exotoxins produced by pathogenic bacteria, such as Clostridium botulinum, Helicobacter pylori, Staphylococcus aureus and Vibrio cholerae.

Extremely strong antioxidant properties exhibit some vitamins: vitamin A, carotenes, vitamin $\mathrm{C}$ and vitamin $\mathrm{E}$. Carotenoids can participate in the protection of the body from damage caused by the action of reactive oxygen species, thereby reducing the risk of cancer incidence. They enhance the proper functioning of immune system, they also influence gene expression. By providing the body with those compounds, we aim at preventing certain diseases caused by free radicals, such as metabolic system diseases, heart and nervous system diseases, diseases of digestive system, lung and skin diseases, heart failure, cerebral embolism, senile dementia, premature aging of human body, apoptosis or cataract [18]. 


\section{Herbs in the human diet}

The oxidation reactions that occur in food products are detrimental to their nutritive value and sensory properties, such as taste, smell, color and texture. Adding antioxidants can effectively counteract those changes, therefore natural ingredients are searched with antioxidant properties to replace synthetic antioxidants applied in food, for example BHA or BHT. An improper diet, rich in lipids, adversely affects the level of free radicals in the body, so it is very important to choose foods with high antioxidant potential. Spices as the ingredients added to almost any meal, no matter which form, can be an excellent source of antioxidants [27]. Spice plants are a very important part of cooking art because they are an indispensable addition to their flavor and aroma and their valuable properties are linked with their biologically active substances, such as essential oils, phenolic compounds, tannins, bitter, organic acids, vitamins, phytoncides and other substances [18]. Oregano and mint oils [19] inhibit the growth of Listeria monocytogenes, Staphylococcus aureus, Escherichia coli and Salmonella typhmurium, whereas Moroccan marjoram inhibits the growth of yeast-like fungi: Candida utilis, C. tropicalis, C. lipolytic and baker yeast Saccharomyces cerevisiae. Epidemiological studies show health effects of polyphenol-rich foods. Polyphenol compounds occurring both in the spices and the herbs are excellent antioxidants to significantly protect human body from oxidative stress together with ascorbic acid, tocopherols and carotenoids.

According to Markowska et al. [25] the major health properties of herbal spices include the following: improving digestive processes, increasing appetite, increasing secretion of gastric juices, beneficially impacting the nervous system and heart rhythm. Their antineoplastic effects (garlic, ginger) have also been proved (Tab. 1).

Herbs are widely recognized as natural and safe products and they are quite commonly used to enhance the effectiveness of official pharmacotherapy or to replace drugs [11]. However in people taking medications those supplements can cause complications associated with their pharmacotherapy as interactions can develop between the ingredients contained in the supplements (vitamins, mineral salts, plant extracts) and the commonly used drugs [45]. Drug interactions with plant extracts are associated with the components contained therein, such as: flavonoids, furanocumarin, alkaloids, terpenes, glycosides, anthocyanins, catechins, biogenic amines, anthraquinones, anthranols and others. Herbs or other plants with the content, for example of anthraquinones or antanols, can affect the absorption of certain drugs since they increase intestinal peristalsis. Such herbs as aloe (Aloe), Sennae folium (Frangulae cortex), Sennae leaf (Sennae folium) are rich in the above mentioned substances and they are often used in mixtures of herbs applied in slimming diets. Other plants or herbs containing 
Table 1. Biologically active compounds contained in some spices and herbs and their therapeutic properties

Tabela 1. Związki biologicznie aktywne zawarte w niektórych przyprawach i ziołach oraz ich właściwości terapeutyczne

\begin{tabular}{|c|c|c|}
\hline $\begin{array}{l}\text { Biologically active } \\
\text { compounds } \\
\text { Związki aktywne } \\
\text { biologicznie }\end{array}$ & Action / Działanie & $\begin{array}{l}\text { Spices and herbs } \\
\text { Przyprawy i zioła }\end{array}$ \\
\hline $\begin{array}{l}\text { Alkaloids } \\
\text { Alkaloidy }\end{array}$ & $\begin{array}{l}\text { analgesic, antitussive, they stimulate the } \\
\text { secretion of digestive juices / przeciwbólowe, } \\
\text { przeciwkaszlowe, pobudzają wydzielanie } \\
\text { soków trawiennych }\end{array}$ & $\begin{array}{l}\text { pepper, fenugreek, black cumin } \\
\text { pieprz, kozieradka, czarny } \\
\text { kminek }\end{array}$ \\
\hline $\begin{array}{l}\text { Anthocyanins } \\
\text { Antocyjany }\end{array}$ & $\begin{array}{l}\text { they improve visual acuity and participate in } \\
\text { oxidative-reducing transformations / wpływają } \\
\text { na poprawę ostrości wzroku, uczestniczą } \\
\text { w przemianach utleniająco-redukujących }\end{array}$ & $\begin{array}{l}\text { basil, thyme, sage, mint } \\
\text { bazylia, tymianek, szałwia, mięta }\end{array}$ \\
\hline $\begin{array}{l}\text { Tannins } \\
\text { Taniny }\end{array}$ & $\begin{array}{l}\text { pickling and bactericidal, anti-diarrhoeal, } \\
\text { aseptic and detoxifying / ściągajace } \\
\text { i bakteriobójcze, przeciwbiegunkowe, } \\
\text { aseptyczne i odtruwające }\end{array}$ & $\begin{array}{l}\text { basil, marjoram, tarragon, bay } \\
\text { leaf } \\
\text { bazylia, majeranek, estragon, liść } \\
\text { laurowy }\end{array}$ \\
\hline $\begin{array}{l}\text { Coumarin } \\
\text { Kumaryna }\end{array}$ & $\begin{array}{l}\text { antibacterial and anticoagulant } \\
\text { antybakteryjne } i \text { antykoagulacyjne }\end{array}$ & $\begin{array}{l}\text { anise, tarragon } \\
\text { anyż, estragon }\end{array}$ \\
\hline $\begin{array}{l}\text { Flavonoids } \\
\text { Flawonoidy }\end{array}$ & $\begin{array}{l}\text { diuretic, antiseptic, antispasmodic, anti- } \\
\text { inflammatory and antioxidant / moczopędne, } \\
\text { antyseptyczne, przeciwskurczowe, przeciw- } \\
\text { zapalne i przeciwutleniające }\end{array}$ & $\begin{array}{l}\text { nettle, thyme, marjoram, anise, } \\
\text { basil, cumin / pokrzywa, } \\
\text { tymianek, majeranek, anyż, } \\
\text { bazylia, kminek }\end{array}$ \\
\hline $\begin{array}{l}\text { Polyphenols } \\
\text { Polifenole }\end{array}$ & $\begin{array}{l}\text { antibacterial, antiviral, anti-inflammatory, } \\
\text { antiallergic, antitumor, antineoplastic } \\
\text { przeciwbakteryjne, przeciwwirusowe, } \\
\text { przeciwzapalne, przeciwalergiczne, } \\
\text { przeciwmutagenne, przeciwnowotworowe }\end{array}$ & $\begin{array}{l}\text { cinnamon, oregano, turmeric, } \\
\text { cumin, basil, ginger, rosemary, } \\
\text { thyme, marjoram / cynamon, } \\
\text { oregano, kurkuma, kminek, } \\
\text { bazylia, imbir, rozmaryn, } \\
\text { tymianek, majeranek }\end{array}$ \\
\hline $\begin{array}{l}\text { Bitters } \\
\text { Gorycze }\end{array}$ & $\begin{array}{l}\text { enhances digestion, antiseptic and anesthetics } \\
\text { properties / wpływają na poprawę trawienia, } \\
\text { mają właściwości antyseptyczne } \\
\text { i znieczulające }\end{array}$ & $\begin{array}{l}\text { yarrow, St. John's wort, nuns, } \\
\text { wormwood, melissa, thyme, } \\
\text { salvia / krwawnik, ziele } \\
\text { dziurawca, mniszek, piołun, } \\
\text { melisa, tymianek, szałwia } \\
\end{array}$ \\
\hline $\begin{array}{l}\text { Glucosinolates } \\
\text { Glukozynolany }\end{array}$ & $\begin{array}{l}\text { they stimulate digestion, they lower blood } \\
\text { sugar and cholesterol levels / pobudzają } \\
\text { trawienie, obniżają poziom cukru we krwi } \\
\text { i poziom cholesterolu }\end{array}$ & mustard / gorczyca \\
\hline $\begin{array}{l}\text { Diastolic and } \\
\text { protective mucous } \\
\text { compounds } \\
\text { Rozkurczowe i } \\
\text { ochronne związki } \\
\text { śluzowe }\end{array}$ & $\begin{array}{l}\text { diastolic and protective (e.g. in the case of } \\
\text { ulcer disease), they counteract constipation, } \\
\text { they facilitate the expulsion / rozkurczające } \\
\text { i osłaniające (np. w przypadku choroby } \\
\text { wrzodowej), przeciwdziałają zaparciom, } \\
\text { ułatwiają odkrztuszanie }\end{array}$ & $\begin{array}{l}\text { flax seed, fenugreek, cinnamon } \\
\text { siemię lniane, kozieradka, } \\
\text { cynamon }\end{array}$ \\
\hline
\end{tabular}




cd. tab. 1
\begin{tabular}{|l|l|l||}
\hline $\begin{array}{l}\text { Phytoncides } \\
\text { Fitoncydy }\end{array}$ & bacteriostatic / bakteriostatyczne & $\begin{array}{l}\text { garlic, onion, rosemary, mint, dill } \\
\text { czosnek, cebula, rozmaryn, mięta, } \\
\text { koperek }\end{array}$ \\
\hline $\begin{array}{l}\text { Saponins } \\
\text { Saponiny }\end{array}$ & $\begin{array}{l}\text { anti-inflammatory in peptic ulcer } \\
\text { przeciwzapalnie w chorobie wrzodowej }\end{array}$ & $\begin{array}{l}\text { liquorice, ginseng, turmeric } \\
\text { lukrecja, żeń-szeń, kurkuma }\end{array}$ \\
\hline $\begin{array}{l}\text { Aromatic essential } \\
\text { oils / Aromatyczne } \\
\text { olejki eteryczne }\end{array}$ & excitatory / pobudzające & $\begin{array}{l}\text { cinnamon, thyme, sage, } \\
\text { rosemary, ginger / cynamon, } \\
\text { tymianek, szałwia, rozmaryn, } \\
\text { imbir }\end{array}$ \\
\hline \hline
\end{tabular}

mucous membranes can also reduce the drug absorption, e.g common flax (Linum usitatissimum), marshmallow (Althaea officinalis) or plantain (Plantago lanceolata L.) for they reduce the access of drugs to mucosa [45].

\section{Conclusions}

A properly formulated diet with herbs or preparations thereof in its composition is able to improve, mainly owing to the antioxidants, the functioning of the body and to prevent the development of certain diseases, such as cancer or atherosclerosis. Spice and herbs used in the diet significantly affect both the taste and the smell of dishes. They can stimulate appetite, increase the secretion of digestive juices, improve the absorption of nutrients and they also have an anti-inflammatory and antibacterial effect. In addition some of them show beneficial effects on the cardiovascular system. The skillful use of herbal spices has a beneficial impact on health especially when consuming hard to digest foods. However, possible interactions between the herbs or preparations thereof and the commonly used drugs can occur.

\section{References}

[1] Ahmad A., Kaleema M., Ahmedb Z., Shafiq H.: Therapeutic potential of flavonoids and their mechanism of action against microbial and viral infections - A review. Food Res. Int., 2015, 77, 221-235.

[2] Błach-Olszewska Z., Długosz A., Kowal-Gierczak B., Lamer-Zarawska E., Niedworok J.: Fitoterapia i leki roślinne. Wyd. I.ek. PZWL, Warszawa 2007.

[3] Chung S., Chung L.Y., Young G., Chhabra S.K., Lee M.: Tea and tea polyphenols in cancer prevention. J. Nutr., 2000, 130, 472-478.

[4] Czerwiecki L.: Współczesne poglądy na rolę przeciwutleniaczy roślinnych w profilaktyce chorób cywilizacyjnch. Roczn. PZH, 2009, 60 (3), 201-206.

[5] Departament Analizy Rynku UOKiK: Raport z badania rynku przypraw w Polsce. Urząd Ochrony Konkurencji i Konsumentów, Warszawa 2007.

[6] Dikbas N., Bagc E., Kotan R., Cakmakci R., Ozer H., Mete E., Erdogan G.: Comparative antibacterial activities and chemical composition of some plants oils against Salmonella enteritidis. Res. Crops., 2010, 11 (1), 118-124.

[7] Dudkowska M., Kucharewicz K.: Związki pochodzenia naturalnego modulujące starzenie i śmierć komórek. Postępy Biochemii, 2014, 60 (2), 207-220. 
[8] Głód B., Kiersztyn I., Piszcz P.: Total antioxidant potential assay with cyclic voltammetry and/or differential pulse voltammetry measurements. J. Electroanal. Chem., 2014, 719, 24-29.

[9] Górnicka J.: Leki z ogrodu. AWM Agencja Wydawnicza, Warszawa 2011.

[10] Grela E.R., Kowalczuk E.: Herbs in animal feeding. Herba Polonica, 2007, 53 (3), 361-366.

[11] Habior A.: Zioła i suplementy diety a ryzyko uszkodzenia wątroby. Gastroenterologia Kliniczna, 2012, 4 (2), 59-68.

[12] Halliwell B.: Antioxidant characterization, methodology and mechanism. Biochem. Pharmacol., 1995, 49, 1341-1348.

[13] Hashemi S.R., Davoodi H.: Herbal plants as a new immune-stimulator in poultry industry. Asian J. Anim. Veter. Adv., 2012, 7 (2), 105-116.

[14] Jambor J.: Zielarstwo w Polsce - stan obecny i perspektywy rozwoju. Herba Polonica, 2007, 5 (2), 22-26.

[15] Kalisz O., Wolski T., Gerkowicz M., Morawski M.: Reaktywne formy tlenu oraz ich rola w patogenezie niektórych chorób. Ann. UMCS Sect. DD, 2007, 62 (1), 87-99.

[16] Kardas M., Toczyńska K., Grochowska-Niedworok E.: Naturalne przyprawy roślinne, skład chemiczny i właściwości prozdrowotne. Charakterystyka przypraw. Przem. Spoż., 2016, 70 (12), 36-40.

[17] Kazimierczak R., Hallmann E., Kazimierczyk M., Rembiałkowska E.: Antioxidants content in chosen spice plants from organic and conventional cultivation. J. Res. Applic. Agric. Eng., 2010, 3 (55), 164-170.

[18] Kazimierczak R., Hallmann E., Sokołowska O., Rembiałkowska E.: Bioactive substances in selected species of medical plants from organic and conventional production. J. Res. Applic. Agric. Eng., 2011, 3 (56), 200-205.

[19] Kozłowska M., Ścibisz I.: Właściwości przeciwutleniające oraz zawartość związków fenolowych w ekstraktach przypraw i ziół z rodziny Lamiaceae. Zesz. Prob. Post. Nauk Roln., 2011, 558, 131-140.

[20] Kumar Jeenger M., Shrivastava S., Yerra G.V., Naidu V.G.M., Ramakrishna S., Kumar A.: Curcumin: A pleiotropic phytonutrient in diabetic complications. Nutrition, 2015, 31, 276-282.

[21] Kumar S., Pandey A.K.: Chemistry and biological activities of flavonoids: An overview. Sci. World J., 2013, \#162750, 1-16.

[22] Lamer-Zarawska E., Kowal-Gierczak B., Niedworok J.: Roślinne antyoksydanty fenolowe w profilaktyce i terapii chorób miażdżycowo-zatorowych. Fitoterapia i leki roślinne. Wyd. Lek. PZWL, Warszawa 2007.

[23] Le Cren F.: Aby żyć dłużej i zdrowiej. Przeciwutleniacze, rewolucja w medycynie XXI wieku. Klub Dla Ciebie, Warszawa 2006.

[24] Majewska M., Czeczot H.: Flawonoidy w profilaktyce i terapii. Farm. Pol., 2009, 656, 369-377.

[25] Markowska J., Polak E., Kasprzyk I.: Ziołowe surowce przyprawowe w przetwórstwie żywności. Przem. Spoż., 2015, 69 (11), 21-25.

[26] Naksuriya O., Okonogi S., Schiffelers R.M., Hennink W.E.: Curcumin nanoformulations: A review of pharmaceutical properties and preclinical studies and clinical data related to cancer treatment. Biomateriale, 2014, 35, 3365-3383.

[27] Newerli-Guz J.: Właściwości przeciwutleniające przypraw na przykładzie pieprzu czarnego Piper Nigrum L. Bromat. Chem. Toksykol., 2012, XLV (3), 887-891.

[28] Nurzyńska-Wierdak R.: Ocimum basilicum L. - wartościowa roślina przyprawowa, lecznicza i olejkodajna. Ann. UMCS, 2012, XXII (1), 20-30.

[29] Nurzyńska-Wierdak R.: Wybrane aspekty aktywności biologicznej flawonoidów. Ann. UMCS, 2016, XXVI (4), 67-78.

[30] Ognik K., Cholewińska E., Sembratowicz I., Grela E.R., Czech A.: The potential of using plant antioxidants to stimulate oxidant mechanisms in poultry. World's Poultry Sci. J., 2016, 72, 291-298.

[31] Olewnicki D., Jabłońska L., Orliński P., Gontar Ł.: Zmiany w krajowej produkcji zielarskiej i wybranych rodzajach przetwórstwa roślin zielarskich w kontekście globalnego wzrostu popytu na te produkty. Zesz. Nauk. SGGW w Warszawie. Problemy Rolnictwa Światowego, 2015, 1 (15), 68-76.

[32] Oszmiański J.: Prozdrowotne polifenole w chorobach serca i naczyń krwionośnych. Przem. Ferm. Owoc.-Warz., 2007, 7 (8), 42-43. 
[33] Papageorgiou V., Mallouchos A., Komaitis M.: Investigation of the antioxidant behavior of air-and freeze-dried aromatic plant materials in relation to their phenolic content and vegetative cycle. J. Agric. Food Chem., 2008, 56, 5743-5752.

[34] Potargowicz E., Szerszenowicz E.: Polifenole roślinne w kosmetyce. Pol. J. Cosmetol., 2006, 9, 7076.

[35] Ramos B., Pilawa B.: Effect of UV irradiation on Echinaceae purpureae interactions with free radicals examined by an X-band (9.3 GHz) EPR spectroscopy. Med. Chem. Res., 2015, 24, 645-651.

[36] Rao P.S., Kalva S., Yerramilli A., Mamidi S.: Free radicals and tissue damage: Role of antioxidants. Free Radicals Antiox., 2011, 1, 2-7.

[37] Rausch A., Lotz B.: Zioła. Leksykon. Wyd. Elipsa, Warszawa 2006.

[38] Rusaczonek A., Świderski F., Waszkiewicz-Robak B.: Antioxidant properties of tea and herbal infusions - A short report. Pol. J. Food Nutr. Sci., 2010, 60 (1), 33-35.

[39] Singh R.P., Sharad S., Kapur S.: Free radicals and oxidative stress in neurodegenerative diseases: Relevance of dietary antioxidants. J. Indian Acad. Clin. Med., 2004, 5, 218-225.

[40] Sobczak P., Żukiewicz-Sobczak W., Kozak M.: Zioła - najzdrowszy dodatek do produktów mięsnych. Gospodarka Mięsna, 2017, 69 (1), 16-19.

[41] Soodi M., Naghdi N., Hajimehdipoor H., Choopani S., Sahraei E.: Memory - improving activity of Melissa officinalis extract in native and scopolamine-treated rats. Res Pharm Sci., 2014, 9 (2), $107-$ 114.

[42] Tarko T.: Występowanie i biodostępność związków polifenolowych oraz możliwości ich wykorzystania w suplementacji żywności. Uniwersytet Rolniczy w Krakowie, Rozprawy, 2014, 401, 12-14.

[43] Valko M., Leibfritz D., Moncol J., Cronin M.T., Mazur M., Telser J.: Free radicals and antioxidants in normal physiological functions and human disease. Int. J. Biochem. Cell Biol., 2007, 39, 44-84.

[44] Yashin A., Yashin Y., Xia X., Nemzer B.: Antioxidant activity of spices and their impact on human health. A review. Antioxidants, 2017, 6 (70), 1-18.

[45] Wolnicka K.: Suplementy diety zawierające składniki roślinne - Ryzyko interakcji z lekami. Żyw. Człow. Metab., 2011, XXXVIII (3), 216-222.

[46] Woźniak M., Ostrowska K., Szymański Ł., Wybieralska K., Zieliński R.: Aktywność przeciwrodnikowa ekstraktów szałwii i rozmarynu. Żywność. Nauka. Technologia. Jakość, 2009, 4 (65), 133-141.

\section{PRZECIWUTLENIAJACE I INNE PROZDROWONE WŁAŚCIWOŚCI ZIÓŁ}

$$
\text { Streszczenie }
$$

Wiele składników zawartych w spożywanych roślinach charakteryzuje się właściwościami przeciwutleniającymi, np. polifenole aktywnie neutralizują wolne rodniki i inne reaktywne formy tlenu. Potencjał przeciwutleniający niektórych roślin zielarskich wielokrotnie przewyższa potencjał owoców i warzyw, dlatego też wzrasta zainteresowanie zawartymi w nich substancjami. Niewłaściwa dieta, np. bogata w lipidy, wpływa niekorzystnie na poziom wolnych rodników w organizmie, dlatego ważne jest, aby wybierać żywność o wysokim potencjale przeciwutleniającym. Reakcje utleniania, jakie zachodzą w produktach żywnościowych są niekorzystne dla ich wartości żywieniowej oraz walorów sensorycznych, takich jak: smak, zapach, barwa, tekstura. Dodatek substancji przeciwutleniających może skutecznie przeciwdziałać tym zmianom, dlatego też poszukuje się naturalnych składników żywności o właściwościach przeciwutleniających, umożliwiających zastąpienie przeciwutleniaczy syntetycznych, takich jak BHA, BHT, które są stosowane w żywności. Działanie przeciwzapalne i antybakteryjne mają niektóre przyprawy ziołowe. Mogą one ponadto stymulować wydzielanie soków trawiennych i podwyższać absorpcję składników pokarmowych. Dieta wzbogacona odpowiednimi ziołami lub uzyskanymi z nich preparatami głównie dzięki zawartym w nich przeciwutleniaczom polepsza funkcjonowanie organizmu i zapobiega rozwojowi niektórych chorób, takich jak nowotwory czy miażdżyca naczyń krwionośnych.

Słowa kluczowe: zioła, przeciwutleniacze, właściwości, oddziaływanie, zdrowie 